\title{
Moms' Empowerment Program participation associated with improved physical health among Latinas experiencing intimate partner violence
}

\author{
Hannah M. Clark, ${ }^{1}$ Andrew C. Grogan-Kaylor, ${ }^{1}$ Maria M. Galano, ${ }^{1}$ Sara F. Stein, ${ }^{2}$ \\ and Sandra A. Graham-Bermann ${ }^{1}$
}

Suggested citation

Clark HM, Grogan-Kaylor AC, Galano MM, Stein SF, Graham-Bermann SA. Moms' Empowerment Program participation associated with improved physical health among Latinas experiencing intimate partner violence. Rev Panam Salud Publica. 2018;42:e39. https://doi.org/10.26633/RPSP.2018.39

\begin{abstract}
Objective. To evaluate whether participation in the Moms' Empowerment Program (MEP), a 10-week, 10-session intervention designed to provide support and increase access to available community resources for women experiencing intimate partner violence (IPV), enhanced the physical health of participants who self-identified as Latina.

Methods. Mothers of children ages 4-12 who self-identified as Latina and had experienced $I P V$ within the past two years were recruited at three intervention sites in Michigan, Ohio, and Texas, via community postings and referrals from agencies serving IPV-exposed families. Selected study participants $(\mathrm{n}=93)$ were assigned to one of two groups: Treatment (immediate enrollment in the MEP) or Control (placement on a waitlist with an invitation to participate in the MEP after the 10-week study period). Data were drawn from two structured interviews, one at the time of recruitment for the study (Time One), and one following the intervention or wait period (Time Two).

Results. After controlling for age, educational attainment, and partner residence (living with a violent partner at the time of the interview), multilevel modeling revealed that improvement in physical health over time was significantly greater among women who participated in the intervention relative to controls.

Conclusions. These data suggest that enhancing interpersonal connectedness and access to resources positively affects physical health for Latinas experiencing IPV.
\end{abstract}

Keywords Intimate partner violence; domestic violence; violence against women; health; Michigan; United States.

In the United States, nearly one in three women experience physical

Department of Psychology, University of
Michigan, Ann Arbor, Michigan, United States of
America. Send correspondence to: Hannah M.
Clark, hdurbin@umich.edu
2 School of Social Work, University of Michigan,
Ann Arbor, Michigan, United States of America.

violence by a current or former intimate partner over the course of their lives (1). Intimate partner violence (IPV), which encompasses physical violence, psychological aggression, sexual coercion, rape, and stalking by a current or former intimate partner, affects millions of men and women each year. Men and women tend to experience IPV at roughly equal rates (2), although women are significantly more likely than men to experience severe forms of IPV, which include being choked, beaten, slammed against something, burned, kicked, and threatened or 
injured with a knife or gun (1). This places women at greater risk for negative health outcomes, which include depression, anxiety, and traumatic stress in addition to physical ailments such as cardiovascular disease, weight gain, diabetes, bone and muscle conditions, chronic pain, respiratory problems, and neurological symptoms $(3,4)$.

An emerging body of evidence suggests that Latinas are especially more likely to experience these negative outcomes associated with IPV. Although it remains unclear whether Latinas are at greater risk for IPV than women who identify as members of other ethnoracial groups (5), women who identify as Latina or Hispanic are consistently more negatively affected by IPV. For example, Edelson et al. (6) found that Latinas experiencing IPV reported lower self-esteem and greater traumatic stress, depression, and parenting stress than non-Latinas, despite experiencing similar levels of IPV. Similarly, other researchers have found that IPV contributes to greater levels of depression and poorer physical health, general mental health, and vitality among Latinas relative to non-Latinas (7). Research with Latinas has replicated earlier findings on the relationships between IPV and physical health. For example, one study (8) examined various physical health outcomes in 33 Latinas with histories of violence exposure. In this sample, IPV exposure was significantly associated with bodily pain, chronic neck and back pain, and frequent headaches. Further, slightly more than half of the sample rated their health as fair/poor. National survey data demonstrate that, in general, Latinas report higher rates of fair/poor overall health compared with White women (9).

Several explanations have been proposed for Latinas' disproportionate risk for adverse outcomes associated with IPV. Some researchers highlight contextual factors, such as language barriers, limited social support, and housing instability (10). Others emphasize social and environmental factors that may pose barriers to care for Latinas, including institutional discrimination, punitive immigration policies, deficiencies in adequate or appropriate services, and lack of responsiveness among advocates (11, 12). Prior research has indicated that enhancing self-efficacy and social support may reduce mental health symptoms among Latinas experiencing IPV (13). Given that limited social support represents both a barrier to care for Latinas and a risk factor for adverse mental health outcomes related to IPV exposure, the authors of this study sought to test whether a similar intervention model would improve physical health symptoms among Latinas experiencing IPV.

\section{The Moms' Empowerment Program}

The Moms' Empowerment Program, or MEP (14), is a 10-session intervention that was designed to address the needs of women experiencing IPV using group therapy with an interpersonal relationship focus. Based in part on Sullivan's interpersonal theory (15), the MEP emphasizes the whole person and explores strengths and abilities that can be used to compensate for biopsychosocial dysfunction. Given the women's histories of violence and abuse, and for many, dysfunction in their family of origin, the program was designed to provide a venue for exploring relationship issues and providing social support. By telling their IPV stories, connecting events to emotional reactions, identifying their fears and worries, and enhancing their selfesteem, the women may reduce their level of distress and begin to recover from past events.

The groups provide a reparative function. Women begin to feel better through association with other women, and by receiving positive responses and support from their peers. It is presumed that, with the support of other women and the therapists, women will find an atmosphere conducive to assessing their concerns and to gaining insights. Along the way, it is hoped that the women participating in the MEP can reduce their distress and begin to heal from the trauma they have endured. Each group consists of two therapists and 5-8 women. The therapists receive clinical training in conducting group work with distressed populations and receive weekly supervision to enhance fidelity to the 10 sessions described in the training manual. In the present study, the 10 sessions were administered weekly across 10 weeks. All women participating in this study self-identified as Latina and spoke Spanish as their primary language. Accordingly, MEP groups were conducted in Spanish by fluent bilingual therapists. Past randomized controlled trials of the
MEP with populations of White and African-American women who have experienced IPV have shown the program to be effective in reducing symptoms of traumatic stress and improving women's parenting $(16,17)$.

This study aimed to evaluate whether participation in the MEP, designed to provide support and increase access to available community resources for women experiencing IPV, enhanced the physical health of participants who self-identified as Latina. It was hypothesized that participation in the MEP would result in greater improvement of women's self-reported physical health over time, relative to waitlist controls. Demographic factors, such as age, educational attainment, and partner residence (living with violent partner) were also expected to correlate with changes in women's perceived health status over time. The authors of this study recognize that health disparities among Latinas who experience IPV are likely the result of transactional processes between many different ecological factors, making the issue of IPV in Latina communities particularly complex to address. This study explores one of many possible avenues for intervention to incrementally improve the lives of Latinas experiencing IPV.

\section{MATERIALS AND METHODS}

\section{Participants and procedure}

The data from this study were derived from a longitudinal study of the MEP for Spanish-speaking Latinas and their children conducted between 2013 and 2015. Study participants $(n=93)$ were recruited in three intervention sites in Michigan, Ohio, and Texas, via community postings and referrals from agencies serving IPV-exposed families. Women who expressed interest in the study were first screened for eligibility, and met criteria if they had a child in the target age range (4-12 years), self-identified as Latina, and had experienced IPV within the past two years. Those who met study criteria $(n=93)$ were then assigned to one of two groups: Treatment (immediate participation in the MEP), or Control (placement on a waitlist with an invitation to participate in the intervention after the 10-week study period). Women were assigned to experimental groups using a block assignment paradigm, which was selected to reduce attrition and 
to minimize the wait time between data collection and participation in the intervention. All study participants were interviewed twice by the study team-once before the intervention period (Time One) and again after the intervention or wait period (Time Two). Within each interview, participants responded to questions about their experiences of violence, their mental and physical health, and basic demographic information. Interviews were administered in Spanish by graduate students and research assistants trained in clinical interviewing and research ethics. Spanish language interviews were translated from their original English versions by a team of researchers fluent in both languages. Interviews were then back-translated by a separate team of research assistants to ensure accuracy.

\section{Measures}

Demographic information. Participants provided basic demographic information, including age and monthly household income. Relationship status was measured using a single survey item with the following response categories: "single," "living with a partner," "married," "separated," "widowed," "divorced," or "remarried." Women were also asked whether they were living with a violent partner at the time of the interview ("partner residence"). Participants' employment status was assessed with the question "Are you working at this time?" and women indicated their highest level of education from one of the following categories: "grade school or less," "some high school," "high school degree/GED," "some college or vocational school," "college degree," "some graduate school," or "graduate degree."

Perceived physical health. Women's general physical health was measured using a single question: "How is your current physical health?" Possible responses ranged from 1 ("very poor" or "muy pobre") to 5 ("excellent" or "excelente $\left.^{\prime \prime}\right)$. Single-item self-report measures of physical health have been found to be strong predictors of mortality (18, 19) and disability (20) in diverse populations, and this item was selected for its accessibility and facility in comparing to national statistics on health status.

\section{Attrition}

A total of 26 out of 93 participants $(28 \%)$ were lost to follow-up at 10 weeks.
Although women who dropped out of the study were significantly more likely to have been assigned to the Control group $\left(\chi^{2}=15.18 ; P<0.001\right)$, there were no significant differences in the data collected on any other study variables at Time One between women who were unable to be located at follow-up and those who completed Time Two interviews.

\section{Analytic strategy}

Multilevel modeling was used to determine whether the improvement in women's self-reported physical health over time was greater for those participating in the MEP relative to those assigned to the Control group. This analytic technique was chosen because it allows and corrects for potential correlations across repeated measures of the same individual, which are likely to occur in within-subjects analyses (21). The multilevel model tested in this study is shown below:

$y_{i t}=\beta_{0}+\beta_{1}$ (Treatment) $+\beta_{2}$ (Time) + $\beta_{3}$ (Treatment $*$ Time $)+\beta_{4}$ (Age) $+\beta_{5}($ Edu cation $)+\beta_{6}($ Partner Residence $) u_{0 i}+e_{i t}$

In the model formula, $y_{i t}$ represents self-reported physical health for each participant $(i)$ at time $(t) ; \beta_{1}-\beta_{6}$ are regression parameters with intercept $\beta_{0} ; \beta_{3^{\prime}}$, the interaction term, denotes the relation between treatment group assignment and changes in self-reported physical health over time, while accounting for women's age, educational attainment, and partner residence; $u_{0 i}$ is a random intercept for each individual; and $e_{i t}$ accounts for the specific variation in the outcome variable on each measurement occasion. Age, educational attainment, and partner residence were included in the model because evidence has indicated that these are factors associated with both IPV and physical health in Latina samples (22-25). All analyses were conducted using STATA 14 statistical software (StataCorp LP, College Station, TX).

Participants provided informed consent before completing each interview and received compensation regardless of whether they responded to all interview questions. Women were informed that their confidentiality would be protected and that all responses would be de-identified. Limits to confidentiality included child safety concerns, which were reported to child protective services. In the case that such a report needed to be made, women were informed. All protocols and procedures were approved by the University of Michigan's Institutional Review Board.

\section{RESULTS}

\section{Descriptive statistics}

Study participants were 35 years of age on average (standard deviation $(\mathrm{SD})=7.31$ ) and reported a monthly household income of approximately US\$ 609.05 (SD = US\$ 490.02). The majority of women participating in the study were single $(82.1 \%)$ and did not reside with a violent partner $(89.5 \%)$ at the time of the initial interview. Less than half $(46.3 \%)$ of participants were employed, and $10.6 \%$ of women had obtained education beyond high school. There were no significant differences between Treatment and Control groups on any study variables at Time One (Table 1).

At Time One, women rated their physical health at an average of $3.37(\mathrm{SD}=1.00)$ out of 5 . The average health score for women in the Treatment group at Time One was $3.29(\mathrm{SD}=1.04)$, while women in the Control group rated their health at an average of $3.48(\mathrm{SD}=0.96)$.

On average, physical health among all participants increased over the 10-week study period $\left(M_{\text {Time } 2}=3.71 ; \mathrm{SD}=0.94\right)$. This general improvement was driven primarily by an increase in self-reported physical health for participants in the Treatment group $\left(M_{\text {Time } 2}=3.80 ; \mathrm{SD}=\right.$ 0.99). Changes in ratings of physical health for participants in the Control group were minimal $\left(M_{\text {Time } 2}=3.52 ; \mathrm{SD}=\right.$ 0.81) (Table 2). The percentage of women who rated their health as "excellent" increased from $10 \%$ at Time One to $25 \%$ at Time Two for the Treatment group, and decreased from $15 \%$ at Time One to $<10 \%$ at Time Two for Control participants. Ratings of "poor" or "very poor" decreased from $19 \%$ to $6 \%$ for participants in the Treatment group, falling well below $16.8 \%$, the national average for those self-identifying as Hispanic or Latino (26).

\section{Multilevel model}

Prior to testing the multilevel model specified above, an estimate of the intraclass correlation coefficient (ICC) was obtained by testing an unconditional model without independent variables. The ICC measured the extent to which 
TABLE 1. Baseline characteristics of participants in study of the effect of the Moms' Empowerment Program (MEP) on the physical health of women self-identified as Latina and experiencing intimate partner violence (IPV), Ann Arbor, Michigan, 2015

\begin{tabular}{|c|c|c|c|}
\hline Characteristic & $\begin{array}{l}\text { All study participants } \\
\qquad(N=93)\end{array}$ & $\begin{array}{l}\text { Treatment } \\
\text { group } \\
(n=53)\end{array}$ & $\begin{array}{l}\text { Control } \\
\text { group } \\
(n=40)\end{array}$ \\
\hline Mean age (SD) & $35.17(7.31)$ & $35.24(7.80)$ & $35.03(6.87)$ \\
\hline Mean health (SD) & $3.37(1.00)$ & $3.29(1.04)$ & $3.48(0.96)$ \\
\hline Education beyond high school (\%) & 10.6 & 9.5 & 10.0 \\
\hline Single $(\%)$ & 82.1 & 81.1 & 82.5 \\
\hline
\end{tabular}

Source: Compiled by the authors based on the results of the study.

a Standard deviation.

${ }^{\mathrm{b}}$ Lives with violent partner.

TABLE 2. Mean health score for participants in study of the effect of the Moms' Empowerment Program (MEP) on the physical health of women self-identified as Latina and experiencing intimate partner violence (IPV), Ann Arbor, Michigan, 2015

\begin{tabular}{lccc}
\hline \multicolumn{1}{c}{ Time of data collection } & & Mean health score $\left(\mathrm{SD}^{\mathrm{a}}\right)$ & \\
\cline { 2 - 5 } & All study participants & Treatment group & Control group \\
\hline At baseline (Time One) & $3.37(1.00)$ & $3.29(1.04)$ & $3.48(0.96)$ \\
Post-intervention (Time Two) & $3.71(0.94)$ & $3.80(0.99)$ & $3.52(0.81)$ \\
\hline
\end{tabular}

Source: Compiled by the authors based on the results of the study.

a Standard deviation.

variation between participants contributed to the estimation of the outcome variable, self-reported physical health (27). Approximately $62 \%$ of the variation in selfreported physical health could be attributed to variation between participants (ICC $=0.62$ ). Results of a likelihood ratio test comparing this model to a model without random effects suggest that including random intercepts for each participant was a superior analytic strategy when compared to ordinary least squares (OLS) regression analyses $\left(\chi^{2}=19.24 ; P<0.001\right)$.

The multilevel model, which included parameters for women's age, educational attainment, partner residence, and group assignment, revealed that age and educational attainment were unrelated to changes in women's physical health over time. The passage of time alone was also not significantly associated with the outcome variable. However, the term for partner residence (cohabitating with a violent partner at the time of the interview) was negatively associated with women's physical health $(\beta=-0.001 ; P=0.04)$.

The interaction term between treatment group assignment and time was associated with an increase in the outcome variable $(\beta=0.477 ; P=0.04)$. The positive direction of the regression parameter indicated that women assigned to the
Treatment group reported greater levels of physical health at Time 2 relative to Controls (Table 3).

\section{DISCUSSION}

This study revealed that improvements in perceived health status were greater among participants in the MEP relative to waitlist controls, supporting the authors' primary hypothesis. Women's age and educational attainment were not significantly related to changes in health status over time. However, partner residence was negatively associated with health status, indicating that women residing with a violent partner reported poorer physical health than women living alone or with a nonviolent partner. On average, women who participated in this study had low levels of socioeconomic resources. Less than half of the study participants reported employment, and the average family income was just over US\$ 600 per month, or US\$ 7200 per year. When data collection for this study began, the U.S. poverty threshold for a family consisting of a woman with two children was US\$ 18769 (28), placing the income of the women in this sample far below that of the poverty threshold. Notwithstanding this context, women benefitted from the MEP. Taken together, these results provide compelling evidence for the theory that increased access to resources and greater social support can improve mental and physical health among women experiencing IPV.

The rates of self-reported fair/poor health in the study sample were consistent with previous research (9) that estimated that approximately one-quarter of Latinas report fair/poor health. Interestingly, age and education status did not have an impact on reported health in this study sample, despite prior evidence suggesting that these factors are related (2225). This may suggest that some other health risk, such as the experience of IPV, has a stronger effect on perceived health in Latinas than either of these factors. In addition, this study found that living with a violent partner had a significant negative impact on perceived health status. Though IPV has been shown to be associated with poorer perceived health even when the IPV has ended, the recency of IPV for women currently living with a violent partner may make the association between IPV and health even stronger.

\section{Limitations}

These findings are limited by a number of factors. Single-item measures of 
TABLE 3. Multilevel model estimating physical health of participants in study of the effect of the Moms' Empowerment Program (MEP) on the physical health of women self-identified as Latina and experiencing intimate partner violence (IPV), Ann Arbor, Michigan, 2015

\begin{tabular}{lcccc}
\hline \multicolumn{1}{c}{ Parameter } & $\boldsymbol{\beta}$ & $\begin{array}{c}\text { Standard } \\
\text { error }_{\beta}\end{array}$ & Z-score & $P$ \\
\hline Treatment & -0.240 & 0.219 & -1.09 & 0.27 \\
Time & -0.009 & 0.190 & -0.05 & 0.96 \\
Treatment ${ }^{\star}$ Time & 0.477 & 0.237 & 2.02 & $0.04^{\mathrm{a}}$ \\
Age & -0.016 & 0.014 & -1.16 & 0.24 \\
Education & 0.169 & 0.089 & 1.90 & 0.06 \\
Partner residence & -0.001 & 0.001 & -2.04 & $0.04^{\mathrm{a}}$ \\
Constant & 3.71 & 0.548 & 6.77 & 0.00 \\
\hline \multicolumn{1}{c}{$\quad$ Variance components } & & Estimate & \multicolumn{3}{c}{0.143} \\
\hline Random intercept & & 0.578 & \multicolumn{3}{c}{0.073} \\
Time & & 0.356 & \multicolumn{3}{c}{} \\
\hline
\end{tabular}

Source: Compiled by the authors based on the results of the study.

${ }^{\text {a }} P<0.05$.

${ }^{\mathrm{b}}$ Lives with violent partner.

self-reported health are common in public health research, and have, for example, been used in large public health studies in Latin America (29). However, future research may benefit from use of a multiitem health status index, as evidence suggests that these measures are even more strongly associated with life expectancy and chronic illness than single-item measures (30). Further, the validity of the single-item health measure in Spanishspeaking populations may depend on its translation. For example, Sanchez \& Vargas (31) found that Spanish-speaking participants responded differently when "fair" was translated to "regular" as opposed to "más o menos," such that the use of "regular" overinflated the reporting of poor health relative to English-speaking respondents. In this study, "fair" was translated to "así así," so the responses from these study participants may not directly compare to national statistics derived from an English-speaking sample.

These findings are also limited in that other factors known to be associated with IPV among women identifying as Hispanic or Latina, such as acculturation (32) or alcohol consumption (23), were not included in the analyses, and the effectiveness of interventions to improve health among women experiencing IPV may be dependent on these factors. Further, although all participants in the present study self-identified as Latina, most had immigrated to the United States from Mexico and all lived within three distinct communities in the United States. Therefore, the results of this study may not generalize to the many populations represented by the term "Latina." Finally, while statistical analyses controlled for a number of covariates, the study sample was recruited from only a few geographic regions in the United States. The authors cannot preclude the possibility that other factors, such as characteristics of the neighborhood in which respondents resided, may have also been associated with the changes in health observed in the present study. Future work on Latina health would benefit from recruiting samples more representative of the Latina population in the United States.

\section{Implications and future directions}

These findings further highlight the overlap between IPV and physical health, and add evidence that there is a need for IPV screening in primary care settings. Research has indicated that most women are never screened for IPV by health care providers (33), and that there is little overlap between women who are screened for IPV and those actually experiencing it (34). Moreover, one of the major barriers preventing providers from screening for IPV is a difference in language or cultural practices (35). Thus, immigrant Latina women who may speak little or no English are likely not receiving IPV screening in health care settings. Given the stigma around help-seeking for IPV (36), screening for IPV in a health care setting is potentially useful as it may be a nonthreatening place for discussing family violence.

Future research directions might include conducting mediation analyses to more fully assess the potential mechanisms explaining the relation between intervention participation and improved health. For example, one might speculate that the improvements in health observed to be associated with the program in this study might be due to increased access to resources or social support. Analyses could also be conducted to assess the functional benefit of improvements in self-reported health. It is possible that increases in self-rated health translate into other positive outcomes such as improved work and family functioning or increased general satisfaction with life.

\section{Conclusions}

This study demonstrates the efficacy of a brief group psychotherapy intervention in improving physical health among Latina mothers experiencing IPV. These findings suggest that even in a context of adversity, a brief, community-based intervention such as the MEP can have positive impacts on women's physical health. Despite facing innumerable barriers to care, including remarkably low levels of socioeconomic resources, the women in this study benefitted from the MEP. Future work in the field could build on the findings from this study to explore the factors mediating the relationship between MEP participation and improved perceived physical health and further refine intervention efforts in order to optimize the health and wellbeing of women and children affected by IPV.

Acknowledgments. The authors wish to thank the women and children who participated in this study, and the research team whose dedication, time, and energy facilitated the successful completion of the project.

Funding. This study was funded by the Office of the Provost's $3^{\text {rd }}$ Century Global Initiative at the University of Michigan and the Blue Cross Blue Shield of Michigan Foundation.

\section{Conflicts of interest. None.}

Disclaimer. Authors hold sole responsibility for the views expressed in the manuscript, which may not necessarily reflect the opinion or policy of the RPSP/ $P A J P H$ or the Pan American Health Organization (PAHO). 


\section{REFERENCES}

1. Breiding MJ, Smith SG, Basile KC, Walters ML, Chen J, Merrick MT. Prevalence and characteristics of sexual violence, stalking, and intimate partner violence victimization National Intimate Partner and Sexual Violence Survey, United States, 2011. MMWR Surveill Summ. 2014;63(8):1-18.

2. National Coalition Against Domestic Violence. National statistics [Internet]. Denver: NCADV; 2015. Available from: https://ncadv.org/statistics

3. Dillon G, Hussain R, Loxton D, Rahman S. Mental and physical health and intimate partner violence against women: a review of the literature. Int J Family Med. 2013;2013:313909. doi: 10.1155/2013/313909.

4. Mason SM, Ayour N, Canney S, Eisenberg ME, Neumark-Sztainer D. Intimate partner violence and 5-year weight change in young women: a longitudinal study. J Womens Health (Larchmt). 2017;26(6):67782. doi: 10.1089/jwh.2016.5909.

5. Clark HM, Galano MM, Grogan-Kaylor AC, Montalvo-Liendo N, GrahamBermann SA. Ethnoracial variation in women's exposure to intimate partner violence. J Interpers Violence. 2016;31(3):53152. doi: $10.1177 / 0886260514555871$.

6. Edelson MG, Hokoda A, Ramos-Lira L. Differences in effects of domestic violence between Latina and non-Latina women. J Fam Violence. 2007;22(1):1-10.

7. Bonomi AE, Anderson ML, Cannon EA, Slesnick N, Rodriguez MA. Intimate partner violence in Latina and non-Latina women. Am J Prev Med. 2009;36(1):43-8. doi: 10.1016/j.amepre.2008.09.027.

8. Kelly UA. Intimate partner violence, physical health, posttraumatic stress disorder, depression, and quality of life in Latinas. West J Emerg Med. 2010;11(3):247-51.

9. Chowdhury PP, Balluz L, Strine TW. Health-related quality of life among minority populations in the United States, BRFSS 2001-2002. Ethn Dis. 2008;18(4):483-7.

10. Vidales GT. Arrested justice: the multifaceted plight of immigrant Latinas who faced domestic violence. J Fam Violence. 2010;25(6):533-44.

11. Kelly UA. "What will happen if I tell you?" Battered Latina women's experiences of health care. Can J Nurs Res. 2006;38(4):78-95.

12. Reina AS, Lohman BJ. Barriers preventing Latina immigrants from seeking advocacy services for domestic violence victims: a qualitative analysis. J Fam Violence. 2015;30(4):479-88.

13. Kelly UA, Pich K. Community-based PTSD treatment for ethnically diverse women who experience intimate partner violence: a feasibility study. Issues Ment Health Nurs. 2014;35(12):906-13. doi: 10.3109/01612840.2014.931496.
14. Graham-Bermann SA. The Moms' Empowerment Program: a training manual. Ann Arbor, MI: Department of Psychology, University of Michigan; 2012.

15. Sullivan HS. The interpersonal theory of psychiatry. New York: W.W. Norton \& Company; 1968. 416 pp.

16. Graham-Bermann SA, Miller LE. Intervention to reduce traumatic stress following intimate partner violence: an efficacy trial of the Moms' Empowerment Program (MEP). Psychodyn Psychiatry. 2013;41(2);329-49. doi: 10.1521/pdps.2013.41.2.329.

17. Howell KH, Miller LE, Lilly MM, Burlaka V, Grogan-Kaylor AC, Graham-Bermann SA. Strengthening positive parenting through intervention: evaluating the Moms' Empowerment Program for women experiencing intimate partner violence. J Interpers Violence. 2015;30(2):23252. doi: $10.1177 / 0886260514533155$.

18. Miilunpalo S, Vuori I, Oja P, Pasanen M, Urponen H. Self-rated health status as a health measure: the predictive value of self-reported health status on the use of physician services and on mortality in the working-age population. J Clin Epidemiol. 1997;50(5):517-28.

19. McGee DL, Liao Y, Cao G, Cooper RS. Selfreported health status and mortality in a multiethnic US cohort. Am J Epidemiol. 1999;149(1):41-6.

20. Pietiläinen $\mathrm{O}$, Laaksonen $\mathrm{M}$, Rahkonen $\mathrm{O}$, Lahelma E. Self-rated health as a predictor of disability-retirement-the contribution of ill-health and working conditions. PLoS One. 2011;6(9):e25004. doi: 10.1371/journal.pone. 0025004 .

21. Singer JD, Willett JB. Applied longitudinal data analysis: modeling change and event occurrence. New York: Oxford University Press; 2003. 644 pp.

22. Castro R, Peek-Asa C, García L, Ruiz A, Kraus JF. Risks for abuse against pregnant Hispanic women: Morelos, Mexico and Los Angeles County, California. Am J Prev Med. 2003;25(4):325-32.

23. Fife RS, Ebersole BS, Bigatti S, Lane KA, Huber LR. Assessment of the relationship of demographic and social factors with intimate partner violence (IPV) among Latinas in Indianapolis. J Womens Health (Larchmt). 2008;17(5):769-75. doi: 10.1089/ jwh.2007.0759.

24. Cunradi CB. Intimate partner violence among Hispanic men and women: the role of drinking, neighborhood disorder, and acculturation-related factors. Violence Vict. 2009;24(1):83-97.

25. Cummings AM, Gonzalez-Guarda RM, Sandoval MF. Intimate partner violence among Hispanics: a review of the literature. J Fam Violence. 2013;28(2): 153-71.
26. Lucas JW, Freeman G, Adams PF. Health of Hispanic adults: United States 20102014. NCHS Data Brief. 2016;(251):1-8.

27. Raudenbush SW, Bryk AS. Hierarchical linear models: applications and data analysis methods. Thousand Oaks, CA: Sage Publications; 2002. 512 pp.

28. United States Census Bureau. Poverty thresholds by size of family and number of children, 2013 [Internet]. Suitland, MD: USCB; 2013. Available from: http://www. census.gov/data/tables/time-series / demo/income-poverty/historicalpoverty-thresholds.html Accessed on 15 December 2017.

29. Lucumí D, Grogan-Kaylor A, EspinosaGarcía G. Asociacíon de la posición socioeconomic y percepción del ambiente con la autopercepción estado de salud en mujeres de Bogotá. Rev Panam Salud Publica. 2013;34(1):14-20.

30. Van Ginneken JK, Groenewold G. A single- vs. multi-item self-rated health status measure: a 21-country study. Open Public Health J. 2012;5(1):1-9. doi: 10.2174/ 1874944501205010001.

31. Sanchez GR, Vargas ED. Language bias and self-rated health status among the Latino population: evidence of the influence of translation in a wording experiment. Qual Life Res. 2016;25(5):1131-6. doi: $10.1007 /$ s11136-015-1147-8.

32. Garcia L, Hurwitz EL, Kraus JF. Acculturation and reported intimate partner violence among Latinas in Los Angeles. J Interpers Violence. 2005;20(5):569-90.

33. Rodriguez M, Shoultz J, Richardson E. Intimate partner violence screening and pregnant Latinas. Violence Vict. 2009;24(4): 520-32.

34. Cha S, Masho SW. Intimate partner violence and utilization of prenatal care in the United States. J Interpers Violence. 2014;29(5):91127. doi: $10.1177 / 0886260513505711$.

35. Beynon CE, Gutmanis IA, Tutty LM, Wathen CN, MacMillan HL. Why physicians and nurses ask (or don't) about partner violence: a qualitative analysis. BMC Public Health. 2012;12:473. doi: 10.1186/ 1471-2458-12-473.

36. Frías SM, Agoff MC. Between support and vulnerability: examining family support among women victims of intimate partner violence in Mexico. J Fam Viol. 2015;30(3): 277-91.

Manuscript submitted 14 December 2016. Revised version accepted for publication on 3 May 2017. 
RESUMEN

La participación en la iniciativa Programa de Empoderamiento de las Mamás, se asocia con mejoría de la salud física de las mujeres latinas objeto de violencia de pareja

Palabras clave Violencia de pareja; violencia doméstica; violencia contra la mujer; salud; Michigan;

Estados Unidos.

Objetivo. Evaluar si la participación en la iniciativa Programa de Empoderamiento de las Mamás (PEM), una intervención de 10 sesiones en 10 semanas concebida para prestar apoyo a mujeres autodefinidas como latinas objeto de violencia de pareja y brindarles un mayor acceso a los recursos comunitarios, mejoró la salud física de las participantes.

Métodos. Participaron en el estudio madres de niños de 4 a 12 años de edad que se autodefinieron como latinas y habían sido objeto de violencia de pareja en los últimos dos años. El reclutamiento de las participantes se hizo en tres sitios donde se realizaba la intervención, en Michigan, Ohio y Texas, por medio de avisos comunitarios y referencias de organismos que atienden a familias expuestas a la violencia de pareja. Las participantes seleccionadas para el estudio $(n=93)$ se asignaron a uno de los dos grupos siguientes: grupo de tratamiento (se inscribieron de inmediato en el PEM) o grupo de control (se pusieron en una lista de espera y se invitaron a participar en el PEM una vez que transcurrieran las 10 semanas del estudio). Se extrajeron datos de dos entrevistas estructuradas, una realizada al inscribir a las participantes en el estudio (fecha 1) y otra después de la intervención o el período de espera (fecha 2).

Resultados. Después de controlar la edad, el nivel de escolaridad y el lugar de residencia de la pareja (vivir con una pareja violenta en el momento de la entrevista), el modelo de varios niveles mostró que el mejoramiento de la salud física con el transcurso del tiempo era significativamente mayor en las mujeres que habían participado en la intervención que en las mujeres del grupo de control.

Conclusiones. Estos datos indican que mejorar la conexión interpersonal y el acceso a los recursos tiene un efecto positivo en la salud física de las mujeres latinas que son objeto de violencia de pareja.
RESUMO

\section{Participação no Programa de Empoderamento de Mães associada à melhora da saúde física em mulheres latinas que sofrem violência infligida pelo parceiro íntimo}

Objetivo. Avaliar se a participação no Programa de Empoderamento de Mães (PEM), uma intervenção composta por 10 sessões semanais com o objetivo de prestar apoio e melhorar o acesso aos recursos disponíveis na comunidade para mulheres que sofrem violência infligida pelo parceiro íntimo, promove a melhora da saúde física das participantes que se reconhecem como latinas.

Métodos. Mães de crianças com idade de 4 a 12 anos que se reconhecem como latinas e sofreram violência infligida pelo parceiro íntimo nos dois anos anteriores foram recrutadas em três centros de intervenção em Michigan, Ohio e Texas, por meio de anúncios na comunidade e o encaminhamento de órgãos que fazem o atendimento de famílias expostas à violência infligida pelo parceiro íntimo. As participantes selecionadas para o estudo $(n=93)$ foram divididas em dois grupos: grupo de tratamento (inscrição imediata no PEM) ou grupo de controle (inscrição na lista de espera com convite para participar do PEM após o período do estudo de 10 semanas). Os dados foram coletados em duas entrevistas estruturadas, uma ao recrutamento para o estudo (momento 1) e a outra após a intervenção ou o período de espera (momento 2).

Resultados. Após controlar idade, nível de instrução e residência do parceiro (coabitação com o parceiro violento no momento da entrevista), a análise com o modelo de múltiplos níveis demonstrou que houve uma melhora significativamente maior da saúde física ao longo do tempo nas participantes da intervenção em comparação ao grupo de controle.

Conclusões. Esses resultados indicam que reforçar o senso de conexão interpessoal e melhorar o acesso aos recursos têm um impacto positivo na saúde física de mulheres latinas que sofrem violência infligida pelo parceiro íntimo.
Palavras-chave
Violência por parceiro íntimo; violência doméstica; violência contra a mulher; saúde; Michigan; Estados Unidos. 